\title{
СОЦИАЛЬНО-ЭКОНОМИЧЕСКИЕ И ЭКОЛОГИЧЕСКИЕ ФАКТОРЫ, ОПРЕДЕЛЯЮЩИЕ РАЗВИТИЕ И ПРОДВИЖЕНИЕ ТУРИСТСКОГО ПОТЕНЦИАЛА КРАСНОДАРСКОГО КРАЯ
}

\author{
Д. С. Тимошенко, С. А. Епринцев \\ Воронежский государственный университет, Россия \\ Поступила в редакичию 1 марта 2019 г.
}

\begin{abstract}
Аннотация: В статье проведена оценка развития туристского потенциала Краснодарского края. Изучено комплексное воздействие социально-экономических и экологических условий на примере Адлерского района города Сочи. Перечислены основные проблемы туристкой индустрии Краснодарского края. Определены перспективные направления продвижения на внутреннем и международном рынке.
\end{abstract}

Ключевые слова: Социально-экономические условия, экологические условия, антропогенные поллютанты, экологический риск, въездной туризм, международный туризм, государственное управление в туризме, маркетинг территорий, брендинг туристских дестинаций.

\section{Socio-economic and environmental factors determining the development and promotion of the tourism potential of the Krasnodar Region}

\section{D.S. Timoshenko, S. A. Yeprintsev}

\begin{abstract}
The article assesses the development of the tourism potential of the Krasnodar region. The complex impact of socio-economic and environmental conditions on the example of the Adler district of the city of Sochi is studied. The main problems of the tourism development are listed. Perspective techniques of tourism destination branding and promoting into domestic and international tourism market are determined.
\end{abstract}

Key words: Socio-economic conditions, environmental conditions, anthropogenic pollutants, environmental risk, inbound tourism, international tourism, public administration, destination marketing, tourism destination branding.

Традиционно развитие отечественных туристских дестинаций формировалось вокруг крупных туристских центров. Для внутреннего туризма исторически характерны массовые путешествия в южном направлении России к Черному морю и отдых на курортах Краснодарского края. Сочи, Горячий ключ, Туапсе, Красная поляна уже стали известными туристскими брендами. Краснодарский край является также центром притяжения самодеятельного туризма. Официальных данных и показателей данной категории туристов нет, так как туристы предпочитают путешествовать на частных автотранспортных средствах и размещаться либо в палаточных лагерях, либо в средствах размеще-

() Тимошенко Д.С., Епринцев С.А., 2019

Материал статьи доступен по лицензии Creative Commons "Attribution" 4.0 ния, владельцы которых не предоставляют отчетности о количестве въезжающих за сезон и сроках их пребывания. Туристские компании отмечают, что отечественные путешественники предпочитают отдыхать в составе семей, самостоятельно и организуют свои поездки без помощи турагентов. Также самостоятельные туристы организуют свой отдых с друзьями и родственниками, приняв решение о путешествии уже после посещения офиса турагентства и ознакомившись с тарифами на отечественный пляжный отдых. Данный скачок в развитии сектора самодеятельного туризма вызван посткризисным эффектом, отсутствием свободных средств для организованных и качественных путешествий, привычкой россиян путешествовать «к морю», которая была нормой во времена СССР и устоявшимся периодом отпусков в летнее время (июнь-август). Комплекс благоприятных климати- 
ческих условий, который эффективно используется в различных направлениях климатотерапии, наличие богатых гидроминеральных ресурсов (минеральные воды, лечебные грязи) и накопленный опыт в сфере реализации туристского продукта и организации санаторно-курортного лечения позволяет отнести г. Сочи к уникальным курортам Российской Федерации [8].

Широко известно, что территория Краснодарского края обладает мощным туристским потенциалом и, обладая спектром разнообразных туристских ресурсов, позволяет формировать привлекательный и комплексный туристский продукт, элементами которого является активный отдых, рекреационный и курортно-оздоровительный туризм, горнолыжный, спортивный, экологический, экскурсионный, этнографический, детский и юношеский туризм, спелеотуризм, поисково-спасательные работы и приключенческие гонки. Краснодарский край является наиболее популярным курортным и туристским регионом России, где в высокий сезон ежедневная загрузка средств размещения составляет приблизительно пятьсот тысяч койко-мест без учета отдыхающих в палаточных городках и отдыхающих, которые размещаются у родственников или друзей без оформления официальной регистрации. Создание на территории Краснодарского края особой экономической зоны (ОЭЗ) туристско-рекреационного типа благоприятно сказывается на реализации комплекса туристского, санаторно-курортного и курортнорекреационного потенциала. Ко всему вышеперечисленному стоит добавить, что Краснодарский край богат уникальными объектами историкокультурного и археологического наследия, охватывающие несколько эпох, начиная с периода античности и средневековья. Комплекс социально-экономических, историко-культурных, природных и экологических факторов создает благоприятные условия для динамичного развития Краснодарского края как конкурентоспособной туристской дестинации.

При этом необходимо подчеркнуть, что экологическая комфортность туристского региона Краснодарского края может быть определена при детальном анализе с учетом трех основных факторов - социально-экономических условий развития территории, комфортности природных условий, а также качества окружающей среды [1].

Стоит обратить внимание на то, что немаловажную роль в состоянии и развитии туристского региона, находящегося под сезонным антропоген- ным прессингом, играет событийный туризм. Так, анализ комфортности урбанизированной территории Адлерского района г. Сочи, исторически находящегося под повышенной антропогенной нагрузкой в летний и «бархатный» сезон, после периода интенсивных строительных работ, обусловленных активной подготовкой к зимним Олимпийским играм 2014 года, показал, что приблизительно $25 \%$ урбанизированной территории характеризуется состоянием сильного загрязнения [2].

Существенный рост антропогенной нагрузки в Адлерском районе города Сочи, который в вопросе городской застройки имеет сложную архитектурную и планировочную структуру, а также подвержен повышенной транспортной нагрузке в высокий сезон туристских прибытий, приходится на период строительства и подготовки объектов зимних Олимпийских игр 2014 года [2]. При неоспоримом положительном экономическом эффекте и модернизации инфраструктуры долгое строительство привело к снижению геоэкологической комфортности для локального населения. Упомянутый негативный фактор может также отрицательно влиять на развитие и продвижение туристского потенциала региона.

Оценка суммарного показателя экологической комфортности в местах интенсифицированного строительства объектов зимних Олимпийских игр в городе Сочи проведена по материалам полевых исследований ЮНЦ РАН (исследование содержания антропогенных загрязнителей в твердых атмосферных выпадениях - тяжелых металлов и пыли в различных частях анализируемой территории) и доклада Росгидромета [2].

Уровни экологической комфортности для населения города Сочи рассчитаны по методике В. В. Приваленко [5] путем анализа содержания антропогенных загрязнителей в твердых атмосферных выпадениях и почве (являющейся своеобразным индикатором качества окружающей среды) при бальном ранжировании каждого исследуемого антропогенного поллютанта. Бальная дифференциация территории в зависимости от уровней загрязненности различными поллютантами производилась от 1 балла (незначительное загрязнение) до 625 баллов (чрезвычайно высокое загрязнение) [2, 5].

Используемая методика оценки экологической комфортности (разработанная В.В. Приваленко) дает объективную оценку ситуации поскольку не позволяет при ранжировании исследуемого участка классифицировать его по интегральному показате- 
лю как территорию с высоким уровнем экологической комфортности при наличии хотя бы одного показателя с высоким уровнем загрязнения [2, 5].

Ранжирование территории города Сочи по уровням загрязнения пылью показало, что более $25 \%$ городских территорий относится к зоне сильного загрязнения. Преимущественное расположение подобных зон - районы строительства объектов и инфраструктуры зимних Олимпийских игр 2014 года. Загрязнение пылью исследуемых урбанизированных территорий происходит преимущественно при ведении интенсивных строительных работ (в атмосферу рассеиваются частицы цемента и других стройматериалов). Загрязнение пылью урбанизированных территорий является фактором риска появления у населения различных экологически-обусловленных заболеваний (преимущественно онкологических и легочных).

Более $35 \%$ городского пространства относится к зоне среднего загрязнения пылью, что может служить причиной определенного дискомфорта для населения. Преимущественное расположение подобных территорий наблюдается вдоль основных автомагистралей города Сочи - дорога соединяющая центр города и Красную поляну. Подобное расположение зоны среднего загрязнения пылью позволяет определить в качестве источника загрязнения помимо строительных работ автотранспортный комплекс, воздействие которого существенно возрастает в летний период.

Экологические условия, классифицируемые как очень опасные для населения наблюдаются в районе путепровода, где в твердых атмосферных выпадениях фиксируется высокие содержания антропогенных поллютантов.

Территории слабого загрязнения пылью расположены на высокогорных участках. Данный факт свидетельствует о влиянии микроклиматических условий и рельефа в формировании очагов данного поллютанта.

Оценка интегрального показателя экологической комфортности для населения городских зон преимущественного рекреационного использования, где проводилось интенсивное строительство олимпийских объектов (Адлерский район города Сочи), позволила выделить 5 типов территорий (рис.).

1. Территория чрезвычайно-низкой комфортности. На данных территориях наблюдается очень сильное антропогенное загрязнение городских ландшафтов. Условия для здоровья населения на данной территории чрезвычайно опасны. На ис-

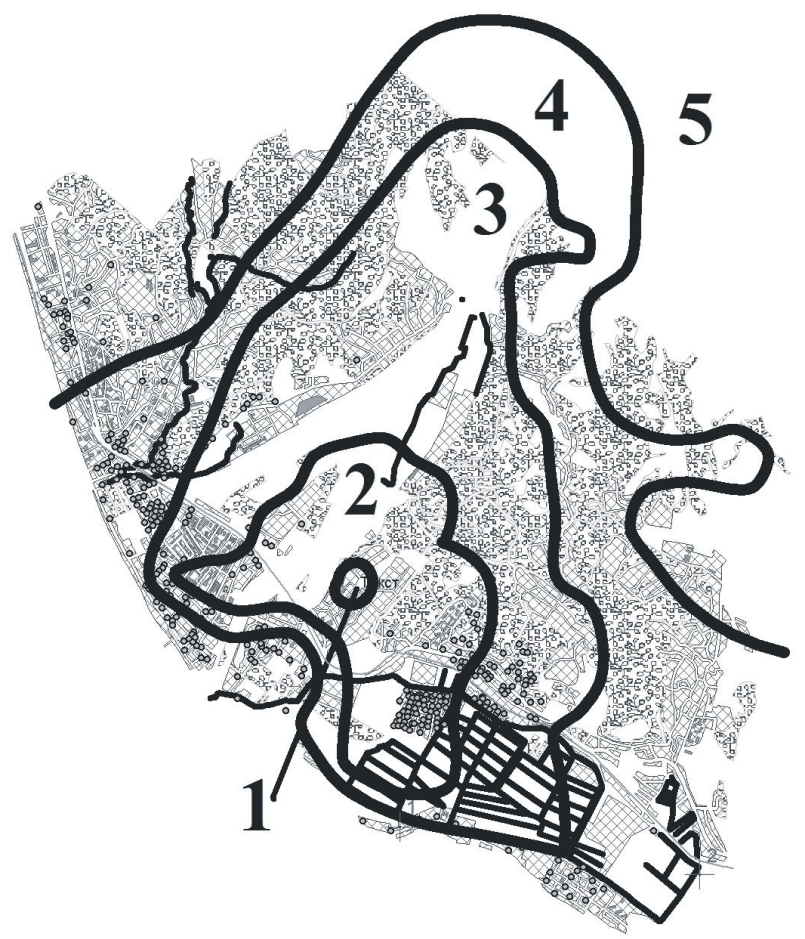

Рuc. Интегральная карта экологической комфортности территории Адлерского района города Сочи (по методике В.В.Приваленко)

Цифрами на карте обозначены:

1 - территория чрезвычайно-низкой комфортности;

2 - территория низкой комфортности;

3 - территория средней комфортности;

4 - территория повышенной комфортности;

5 - территория высокой комфортности.

следуемой территории города Сочи данная зона не велика (не более 2\%) - территория путепровода. Основной фактор ее формирования - автотранспортный комплекс.

2. Территория низкой комфортности. Совокупность экологических условий определяет данную территорию как опасную для здоровья населения. Размеры данной территории в пределах $15 \%$ городского пространства. Расположение данной зоны наблюдается в районах аэропорта, морского порта, а также в прошлом фиксировалась в районах проведения активных строительных работ.

3. Территория средней комфортности. Экологические условия данной территории, определяют удовлетворительные условия для здоровья населения. В городском пространстве данная зона занимает $30 \%$. Расположена по периферии территории низкой комфортности. Причиной ее формирования служит перенос антропогенных поллютантов с потоками ветра.

4. Территория повышенной комфортности $25 \%$ городского пространства. Здесь наблюдаются хорошие экологические условия для здоровья 
населения. Расположена на достаточном удалении от основных источников антропогенного загрязнения.

5. Территория высокой комфортности - оптимальные экологические условия для здоровья населения. Занимает $25 \%$ городского пространства. Расположена на территории горных массивов, где в наименьшей степени ощущается негативное антропогенное воздействие на атмосферу.

При этом стоит подчеркнуть, что проведение таких крупномасштабных международных событий мирового значения как XXII зимние Олимпийские игры, Одиннадцатые Паралимпийские игры в Сочи, Чемпионат мира по футболу 2018 года, а также проведение этапа Формулы-1 привлекли глобальное внимание и принесли региону всемирную известность. За годы подготовки к этим событиям г. Сочи практически полностью преобразился, существенно обновил и развил туристскую, гостиничную и спортивную инфраструктуры горного и прибрежного кластеров.

Приход в регион Газпрома, развитие инфраструктуры, строительство объектов и реализация масштабных проектов трубопроводных сооружений также повысил интерес инвесторов к региону.

Необходимо отметить ряд важнейших факторов, определяющих динамику развития туризма Краснодарского края в последние годы. В первую очередь, финансово-экономические кризисы 2008 и 2014 годов значительно повлияли на ценовую политику как в международном, так и во внутреннем туризме, а также на процессы формирования туристских пакетов и взаимных расчетов с принимающей стороной за рубежом. Ослабление рубля на финансовом рынке, резкие перепады цен на зарубежный туристский продукт не в пользу увеличения покупательской способности россиян, напряженная социально-экономическая и политическая обстановка, острые вопросы обеспечения безопасности туристов, находящихся за пределами Российской Федерации, существенно повлияли на покупательскую способность россиян в вопросах приобретения туристских услуг [7, 8].

Одновременно перечисленные факторы способствовали стабильному росту числа туристских прибытий в Краснодарский край (11,9 млн 2012 г., 11,8 млн - 2013 г., 13,8 млн - 2014 г., 16 млн - 2015 г., 15,8 млн - 2016 г. 16 млн - 2017 г.) [4]. Динамичное развитие туристского комплекса дестинации генерирует налоговые поступления в государственный и местный бюджет, стимулирует рост показателей смежных с туризмом отраслей экономики и снижает уровень безработицы. На конец 2017 года среднеотраслевая заработная плата в туризме по данным Министерства курортов, туризма и олимпийского наследия Краснодарского края достигла 33,5 тыс. руб.; объем услуг курортно-туристского комплекса составил 121,8 млрд. руб. (данные представлены с учетом неорганизованного сектора); объем налоговых поступлений от предприятий санаторно-курортного комплекса - 7,1 млрд. руб. [4]. Провести объективную и точную оценку реального снижения бюджетной эффективности в секторе индивидуальных средств размещения не представляется возможным, ввиду отсутствия статистического инструментария учета туристских прибытий, учета самих средств размещения и квартиросдатчиков, а также несовершенного законодательства, что приводит к сокрытию налогов порядка 80 \% индивидуальных средств размещения.

В динамике последних десяти лет Краснодарский край значительно увеличил свою конкурентоспособность, усовершенствовал политику туристского продвижения, что среди всего прочего обусловлено активной исследовательской работой локальных научных институтов, успешными и регулярными презентациями туристского продукта региона на крупнейших международных туристских выставках, активной работой с партнерами, инвесторами, заинтересованными лицами, потенциальными и постоянными туристами в социальных сетях. Введение минимального курортного сбора в регионе - еще один шаг к повышению уровня культуры туристского потребления в регионе.

Среди факторов, сдерживающих темп эффективного туристского развития стоит отметить неравномерность распределения инфраструктуры туристского комплекса, низкое качество обслуживания в сегменте экономичного и массового туризма, отсутствие организованных площадок для емкого сегмента автотуристов, которые едут на курорты Краснодарского края со всей России, недостаточная квалификация персонала (в том числе низкий уровень туристкой культуры, профессиональной этики, владения иностранным языком) в секторе туристского, ресторанного, гостиничного и экскурсионного обслуживания, что особенно характерно для индивидуальных средств размещения и «теневых» индивидуальных предпринимателей. Безусловным успехом региона является ежегодное проведение Российского инвестиционного форума и профильных выставок в период низкого туристского сезона, что служит привлече- 
нию инвестиций в регион и является конструктивной площадкой для ведения диалога, затрагивающего интересы как Краснодарского края, так и будущего всей страны.

Однако ключевыми проблемами устойчивого туристского развития, комплексного регионального развития и продвижения туристского потенциала Краснодарского края являются неравномерная антропогенная нагрузка на регион в целом, критическое значение присутствующих антропогенных поллютантов, повышенный экологический риск для местного населения, что среди всех прочих негативных факторов вызвано присущей региону сезонностью в оказании туристских услуг. Перед Краснодарским краем в настоящее время стоят вопросы не столько динамичного увеличения числа туристских прибытий, сколько повышения общей культуры туризма, присутствующего в регионе, перераспределения туристских потоков через поиск новых форматов реализации турпродукта и услуг, одновременного сохранения туристской идентичности дестинации, сохранения экологической комфортности территории для будущих поколений местного населения и гостей региона.

Обозначенные проблемы могут быть решены путем проработки новых сегментов рынка, поиска и реализации новых туристских форматов MICE, conference-tourism, FIT, B2B, B2A, образовательного и делового туризма для расширения спектра целевой аудитории [8, 9], оптимизации антропогенной нагрузки на регион, формирования краткосрочных и долгосрочных календарей событий с учетом эффективного планирования загрузки гостиничных фондов в течение всего календарного года. Это позволит перераспределить ярко выраженную сезонную антропогенную нагрузку на регион, повысить уровень экологической комфортности туристской дестинации, вести более гибкую ценовую политику туристских предложений и повысить конкурентоспособность туристского продукта Краснодарского края.

Исследования проведены при поддержке РФФИ (проект 19-05-00660 А).

\section{СПИСОК ЛИТЕРАТУРЫ}

1. Епринцев С. А. Оценка экологической комфортности населения урбанизированных территорий / С. А. Епринцев // Вестник Тамбовского университета. Сер. Естественные и технические науки. - 2014. - Т. 19, № 5. - C. 1410-1412.

2. Епринцев С. А. Экологическая комфортность урбанизированной территории Адлерского района города Сочи в условиях интенсивного антропогенного прессинга / С. А. Епринцев // Вестник Воронежского государственного университета. Сер. География. Геоэкология. - 2012. - № 2. - С. 100-104.

3. Официальный портал Федерального агентства по туризму. - URL: http://russiatourism.ru (дата обращения 18.02.2019).

4. Официальный сайт Министерства курортов, туризма и олимпийского наследия Краснодарского края. - URL: https://min.kurortkuban.ru/ (дата обращения 18.02.2019).

5. Приваленко В. В. Экологические проблемы антропогенных ландшафтов Ростовской области / В. В. Приваленко, О. С. Безуглова. - Ростов-на-Дону : Издательство СКНЦ ВШ, 2003. - Т. 1. Экология города Ростов-на-Дону. -290 с.

6. Стратегия социально-экономического развития Краснодарского края до 2020 года // Сайт министерства экономики Краснодарского края. - URL: http:// economy.krasnodar.ru/strategic-planning/the-strategy-ofdevelopment-of-krasnodar-region/ (дата обращения 12.02.2019).

7. Тимошенко Д. С. Проблемы развития туристического рынка Российской Федерации и подготовки профессионально ориентированных кадров сферы туризма в период мирового финансово-экономического кризиса / Д. С. Тимошенко // Цивилизация знаний: глобальный кризис и инновационный выбор России. 2009 : труды 10-й Международной конференции. - Москва : PocHOУ. - 2009. - Ч. 1. - С. 489-493.

8. Тимошенко Д. С. Роль брендинга туристских дестинаций в Российской Федерации / Д. С. Тимошенко // Экономические и гуманитарные науки. - 2010. № 12(227). - С. 132-136.

9. Тимошенко Д. С. Формирование технологии продвижения туристских услуг на региональном уровне : дис. ... канд. экон. наук / Д. С. Тимошенко. - Москва, 2013. - $210 \mathrm{c}$.

10. Унифицированный туристский паспорт. - URL: http://utp.nbcrs.org/\#about (дата обращения 12.02.19)

11. Федотов В. И. Континентальный туризм в России / В. И. Федотов, С. В. Федотов, Т. С. Федотова // Вестник Воронежского государственного университета. Сер. География. Геоэкология. - 2015. - № 4. - С. 5-14.

\section{REFERENCES}

1. Eprintsev S. A., Otsenka ekologicheskoy komfortnosti naseleniya urbanizirovannykh territoriy [Assessment of the environmental comfort of the population of urban areas]. Vestnik Tambovskogo universiteta. Ser. Estestvennye $i$ tekhnicheskie nauki, 2014, Vol. 19, No. 5, pp. 1410-1412.

2. Eprintsev S. A., Ekologicheskaya komfortnost' urbanizirovannoy territorii Adlerskogo rayona goroda Sochi v usloviyakh intensivnogo antropogennogo pressinga [Ecological comfort of the urbanized territory of the Adler district of Sochi in conditions of intense anthropogenic pressure]. Vestnik Voronezhskogo gosudarstvennogo universiteta. Ser. Geografiya. Geoekologiya, 2012, No. 2, pp. 100-104. 
3. Ofitsial'nyy portal Federal'nogo agentstva po turiz$m u$ [The official portal of the Federal Agency for Tourism]. Available at: http://russiatourism.ru (accessed 18 February 2019).

4. Ofitsial'nyy sayt Ministerstva kurortov, turizma i olimpiyskogo naslediya Krasnodarskogo kraya [The official website of the Ministry of Resorts, Tourism and Olympic Heritage of the Krasnodar Territory]. Available at: https:// min.kurortkuban.ru/ (accessed 18 February 2019).

5. Privalenko V. V., Bezuglova O. S., Ekologicheskie problemy antropogennykh landshaftov Rostovskoy oblasti [Environmental problems of anthropogenic landscapes of the Rostov region]. Rostov-na-Donu, Izdatel'stvo SKNTs VSh, 2003, Vol. 1. Ekologiya goroda Rostov-na-Donu, $290 \mathrm{p}$.

6. Strategiya sotsial'no-ekonomicheskogo razvitiya Krasnodarskogo kraya do 2020 goda, Sayt ministerstva ekonomiki Krasnodarskogo kraya [Strategy for socio-economic development of the Krasnodar Territory until 2020]. Available at: http://economy.krasnodar.ru/strategic-planning/the-strategy-of-development-of-krasnodar-region/ (accessed 12 February 2019).

7. Timoshenko D. S., Problemy razvitiya turisticheskogo rynka Rossiyskoy Federatsii i podgotovki professional'no orientirovannykh kadrov sfery turizma $\mathrm{v}$ period mirovogo

\section{Тимошенко Диана Сергеевна}

кандидат экономических наук, доцент кафедры рекреационной географии, страноведения и туризма Воронежского государственного университета, г. Воронеж, т. +7(473) 266-56-54, E-mail: artemideus@ gmail.com

Епринцев Сергей Александрович кандидат географических наук, доцент кафедры геоэкологии и мониторинга окружающей среды Воронежского государственного университета, г. Воронеж, т. +7(473) 266-56-54, E-mail: esa81@ mail.ru finansovo-ekonomicheskogo krizisa [Problems of developing the tourism market of the Russian Federation and the training of professionally oriented personnel in the tourism industry during the global financial and economic crisis]. Tsivilizatsiya znaniy: global'nyy krizis i innovatsionnyy vybor Rossii. 2009: trudy 10-y Mezhdunarodnoy konferentsii (The civilization of knowledge: the global crisis and Russia's innovative choice. 2009: proceedings of the 10th International Conference). Moscow, RosNOU, 2009, Vol. 1, pp. 489-493.

8. Timoshenko D. S., Rol' brendinga turistskikh destinatsiy v Rossiyskoy Federatsii [The role of branding of tourist destinations in the Russian Federation]. Ekonomicheskie i gumanitarnye nauki, 2010, No. 12(227), pp. 132-136.

9. Timoshenko D. S., Formirovanie tekhnologii prodvizheniya turistskikh uslug na regional'nom urovne [The formation of technology for promoting tourism services at the regional level]. Moscow, 2013, 210 p.

10. Unifitsirovannyy turistskiy passport [Unified tourist passport]. Available at: http://utp.nbcrs.org/\#about (accessed 12 February 2019)

11. Fedotov V. I., Fedotov S. V., Fedotova T. S., Kontinental'nyy turizm $\mathrm{v}$ Rossii [Continental tourism in Russia]. Vestnik Voronezhskogo gosudarstvennogo universiteta. Ser. Geografiya. Geoekologiya, 2015, No. 4, pp. 5-14.

Timoshenko Diana Sergeyevna

Candidate of Economic Sciences, Lecturer at the Department of Recreational Geography, Regional Geography and Tourism, Voronezh State University, Voronezh, t. +7(473) 266-56-54, E-mail: artemideus@gmail.com

Yeprintsev Sergey Alexandrovich

Candidate of Geographical Sciences, Associate Professor at the Department of Geoecology and Environmental Monitoring, Voronezh State University, Voronezh, t. +7 (473) 266-56-54, E-mail: esa81@ mail.ru 